\title{
An Assessment Of Business Schools' Student Retention, Accreditation, And Faculty Scholarship Challenges
}

Frank J. Cavico, Nova Southeastern University, USA

Bahaudin G. Mujtaba, Nova Southeastern University, USA

\begin{abstract}
Business schools' curriculum, faculty and graduates have become a target for many critics as they link the ethical lapses of senior executives to major scandals that have partially led to the financial challenges that the world is facing today. Some claim that business faculty research is not practical and mainly theoretical. This paper discusses the current state of affairs in business education, business school quality control through accreditation guidelines, and faculty scholarship in order to consistently keep faculty up-to-date on the latest research. The paper also offers reflections, suggestions, and practical tips for student recruitment and retention.
\end{abstract}

Keywords: Business education; mission; accreditation; scholarship; and student retention.

\section{INTRODUCTION}

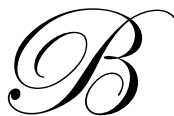

usiness schools and business students compete with people from across the globe who have diverse cultural orientations. Critics claim that business schools focus too much on the achievement of the "bottom-line" at all costs, and that this indoctrination has led to unethical behaviors and scandals associated with Enron, Tyco, WorldCom, and other such firms, as well as the current mortgage real estate banking crises (Cavico and Mujtaba, 2009). According to Neubaum, Pagell, Drexler, McKee-Ryan, and Larson (2009), "many of the recent discussions of business schools have centered not on the good their graduates do, but on how the theoretical foundations of business school education may be linked to ethical lapses and scandals involving managers who have been subjected to business school training" (p. 9). The critics argue that business school faculty members teach such concepts as transaction-based economics, economic liberalism, or agency theory to students, which focus on short-term profits, even if this narrow approach comes at a cost of damaging long-term opportunities and relationships with customers, suppliers, vendors as well as society as a whole(Mujtaba and Cavico, 2009). Ghoshal states that "business schools have actively freed their students from any sense of moral responsibility" because faculty members teach theories that are ideological in nature (2005, p. 76).

According to Bennis and O'Toole (2005), business schools are facing heavy criticism for failing to impart useful skills and knowledge, prepare leaders for doing what is right, instill norms of ethical behavior that would have prevented major corporate debacles; and even for failing to lead graduates to professionals jobs that can pay them good wages. The root cause of these problems in management education, according to Warren G. Bennis and James O'Toole, is that most business schools seem to have adopted a self-defeating model for assessment of academic excellence. Instead of measuring the quality of each program in terms of the competence of students, most schools assess themselves based on the "rigor" of scientific research that is published by their faculty and graduates. This model might be appropriate in dentistry, medicine, or chemistry, but perhaps not for business schools. Business schools rather should use a practitioner-oriented model. However, the reality is that most business schools continue to hire and promote research-oriented professors who have never spent time working in the workplace. Since these research-focused faculty members are comfortable teaching methodology and scientific research, business schools will continue to groom graduates of the same caliber. To become competitive and relevant for the modern workplace, business schools need to rediscover the practice of business, while effectively balancing the need for 
educating practitioners and creating knowledge through scientific research.

While business school curricula do teach scientific research, efficiency, accuracy, operations management, and economic theories, they also teach students about value creation by maintaining a healthy relationship with their suppliers, colleagues, unions, government entities, and communities for the long-term sustainability of their success. This value creation must be aligned with the school's vision, mission, accreditation guidelines, and faculty scholarship.

\section{MISSION, CHALLENGES, AND OPPORTUNITIES}

Business schools today, especially competitive private schools in this very difficult economic climate, must provide an excellent education to their students. They must offer a wide variety of programs and courses to the students at times and places convenient to the students. Schools must have the freedom to operate - geographically and "virtually," that is, by modes of delivery, and should seek to be less constrained, whenever possible, by "political" factors. Schools thus should be flexible, and certainly so must be private schools that are "nontraditional," in order to reach individuals who are not in a conventional academic mode, such as working professionals. A fundamental mission of business schools is to help students find employment opportunities, particularly when jobs are scarce in a recessionary economy. Yet there is a larger goal, and that is to produce students who will be business leaders, innovators, and entrepreneurs, who will build a stronger and sustainable economy locally and globally.

The business environment for schools of business is certainly a very competitive one today. There are state schools and private schools; there are traditional, innovative, and entrepreneurial schools; there are non-profit and for-profit schools; there are ground-based and online schools; and there are combinations of the foregoing. They are all aggressively searching for students. There is also a faculty shortage, especially doctoral faculty. Moreover, due to the recessionary economy, producing less government contributions and less endowment revenues, schools are now moving into marketing areas they once eschewed. These factors amount to a "perfect storm" for business schools. To vividly illustrate the nature of the very challenging marketplace today confronting business schools, let us relate two incidents, occurring on the same day. In a leading newspaper of South Florida, Sun-Sentinel, there appeared a large, bright orange, sticker on the cover of the paper. The sticker was in the colors of the University of Florida, located several hours away in Gainesville, advertising a new online, master's program, in entrepreneurship offered by that university's school of business. On the very same day, there appeared on the front page of the Marketplace section of The Wall Street Journal an article (Glader, 2009), titled "The Jack Welch MBA Coming to Web," which discussed the former General Electric CEO's financial and advisement relationship with a very entrepreneurial school, called Chancellor University, and its incipient online MBA program. Masters of Management as well as undergraduate business degree programs are also being planned. The emphasis, as per the philosophy of Mr. Welch, will be on quality, leadership, and human resources. Such is the nature of competition facing business schools, particularly mid-tiered, tuition-driven schools, which are being "squeezed" by the more traditional and the newer for-profit entrepreneurial schools. When a large, traditional, state school like the University of Florida commences a specialized online business program, and then advertises the program far from its home "turf," it is time for all schools to take notice. High-level strategic planning and decision-making thus must occur as to what programs and courses to offer as well as to determine which ones are draining resources so they can be dropped. A school must aggressively search out and identify market opportunities, and then seek to secure a differential competitive advantage in markets where it deems it can be successful. The keys to sustainability and growth are innovation and entrepreneurship, which mean new ideas are imperative, and some risks must be taken. A school, therefore, must be on the "leading edge of change," yet be very nimble and not full off the edge. Flexibility is important since nobody wants the "leading edge" concept to be converted to a "bleeding edge."

Schools of business, therefore, must be able to engage students, provide them with high quality, innovative, and entrepreneurial academic experiences, and thus afford them career opportunities. Schools must consider both the traditional and non-traditional aspects of business education - and not only in delivery modes but in content too. Yet schools must be practical and first focus on programs within their capabilities that are in the greatest demand, and thus will produce immediate revenue and long-term value. To illustrate, "differentiated" MBAs, specialized MBAs, and degrees with competitive pricing, and encompassing day, evening, weekend, online, and hybrid modalities are 
essential in this very competitive business and academic environment. Programs and courses could also be "blended," that is, combine disciplines. For example, a blended business course focusing on the consumer or customer would include in addition to the traditional marketing subject matter, material encompassing elements of psychology, sociology, economics, ethics, accounting, and information technology. Programs could have a global theme, such as global energy, finance, and economics. Students must be provided the content and skills to enable them to compete in the global marketplace. International partnership programs, particularly cross-disciplinary and MBA programs, emerge as viable opportunities. In a global energy MBA, for example, there could be specialized MBA energy courses. Courses could be offered in "Global Finance" or "Managing the Global Economy." These international programs and courses would demonstrate the complexity and inter-relatedness of the global economy. Due to the recessionary economic climate, attention should be paid to finance courses, such as a personal finance course for all business students (or for that matter for all the college's or university's students) or a finance and trading course for more advanced students. Leadership, the environment, and healthcare are also emerging fields and thus ripe for specialized programs. Entrepreneurship programs will possess a new and critical importance as the potential and luster of a corporate career may have been dimmed. Executive MBA programs may be another viable alternative for schools. Such programs could focus on a particular company or industry, or have an international component, including an extensive field trip to a foreign company to meet with government and business leaders. Programs and courses could be created that would provide immediate tangible benefits for companies sponsoring their employees as students. In the human resources fields, courses and programs could be built around the "soft skills," such as communication, mediation and arbitration, brokering compromises, team building and managing, avoiding conflict, dispelling rumors, and advising, mentoring, and managing virtually or at a distance. In addition to leadership and human resources, programs and courses could be developed highlighting "intrapreneurship," process management and improvement, supply chain management, and logistics, and, furthermore, these programs and courses could be geared to specific companies and industries. Another example is the "Green MBA" or "EcoMBA," wherein students study, in addition to traditional business skills and knowledge, social and environmental issues and sustainable business practices and focus on the "triple bottom-line" of "people, planet, and profit" (Brant and Ohtake, 2008). In addition to helping save the planet, another goal of "going green" is to give the students a competitive edge. The "green" programs recognize that in order to be globally competitive in today's economy, the students must have an understanding of the risks as well as opportunities that the natural environment presents to business (Locke, 2007).

Creating Business Consulting, Small Business, Entrepreneurship, Trading, and Business Ethics centers is another good way to produce value for the school and its stakeholders. The Trading Center could establish an investment fund dedicated to socially responsible investing, so as to provide to the students a unique and very practical as well as socially responsible learning experience (Alsop, 2007). The Entrepreneurship Center, in addition to advising and counseling, could have a Business Plan competition. The administration, faculty, students, business leaders, and community would be involved; valuable consulting services and guest lecturers would be provided; certificate programs, for example in entrepreneurship, innovation, and leadership, would be offered; and the reputation of the school thereby enlarged and enhanced within the community, including potential students and charitable donors. Schools, therefore, must reach out to students, and on a global basis, and with a variety of programs, joint programs, strategic alliances and partnerships; schools thus must be "comprehensive," but also cognizant of demand as well as financial ramifications and delivery capabilities.

It is critically important for schools of business to align what they plan to teach with what the students need to know to be successful. Ultimately, the students have to be shown that their education will produce direct value in the form of employment or entrepreneurship. Therefore, it is essential that schools build a "platform" or a foundation for learning, as well as create a stimulus for continuous learning. Schools of business must develop not only the critical analytical skills of their students, but also must foster creative and innovative thinking, so the students can be successful business leaders, managers, and entrepreneurs. A school must motivate the students and teach them how to think differently about business. What are the new markets, the new products, the new services? What are the entrepreneurial and intraprenurial opportunities? Those would be key questions to attempt to answer. The goal is for the students to be leaders and "shapers" and not mere followers and "reactors." Students must leave school thinking, and in particular thinking, "How can we do things differently?" 
Schools, particularly state schools and the more traditional, "bricks and mortar" private schools should be concerned about becoming too "centralized" and too conservative and consequently creating further structural and mental impediments to change. They may now have to be a bit more innovative, entrepreneurial, and "progressive." At times, it may be easier for a school to be more traditional as opposed to innovative. Yet a school in today's environment must be very careful about being too traditional. Modern schools must abjure the old "if you build it, they will come" philosophy, because such a school will not survive in this competitive environment. A school, fundamentally, must have a "brand" - a unique and valuable and value-creating brand - one that produces excellent value for the students. The school must seek out opportunities, marshal resources, and make this brand visible and operational in clearly chosen markets, and show how this "brand" can provide a direct, immediate, and measurable return to the students (and their parents and perhaps corporate sponsors) for their educational investment.

\section{ACCREDITATION CHALLENGES FOR BUSINESS SCHOOLS}

Regional accreditation is important for a business school to be regarded as a reputable academic institution. Yet should schools of business also seek to obtain accreditation by the Association to Advance Collegiate Schools of Business (AACSB)? Is AACSB accreditation essential for successful schools of business? Is the growth for nonAACSB schools going to come from securing accreditation, or are there other options? Do the benefits of AACSB accreditation outweigh the costs? Would a school be better off in spending its money creating superior programs than seeking AACSB accreditation? Some schools may have a very good, innovative, and entrepreneurial model, and be very successful and produce successful students, without any accreditation, let alone AACSB accreditation. After all, the "marketplace is the best accreditor." Moreover, the true test of a school is the marketplace; that is, if a school delivers what it promises, produces value for its students, the community, and society, and the market recognizes and rewards such value production, then the school may be as well off without accreditation, and it actually may be worse off with it. Yet the authors are not blind to the "political reality" of AACSB accreditation. So, evidently, such accreditation must be closely examined.

The first and foremost issue is the value of AACSB accreditation to a school. The authors have had many discussions with faculty colleagues and with academic administrators at their own school and other schools, especially current and former deans, regarding AACSB accreditation. The clear consensus is that such accreditation is regarded as synonymous with "quality" and legitimacy. The authors have repeatedly heard such descriptive phrases as "brand enhancer," "gold seal," "gold standard," "top one," "hallmark," "must have," "essential," "ticket to success," and "top level" being applied to the AACSB accreditation. Many members of the academic business community regard such certification as "imperative" for a school to be regarded as a "major player" and thus to be competitive in today's challenging academic "market."

There are, of course, other entities that rank business schools; and accordingly perhaps one can be a bit creative in "playing the rankings game," for example, by seeking out other recognitions, such as by the Wall Street Journal, Business Week, US News \& World Report, and recruiters' rankings, that might be less costly, and perhaps easier, for a school to achieve. There are also other alternative accrediting bodies, such as the International Assembly for Collegiate Business Education (IACBE), the regional ones such as the Southern Association of Colleges and Schools (SACS), and the newer international one, EQUIS, the European Quality Initiative for Schools. Yet there is no denying that AACSB has done an excellent job in "branding" its accreditation designation. For example, the authors have heard "talk" that there is an AACSB initiative to persuade employers not to provide tuition assistance for employees who do not attend AACSB accredited schools and, even more controversial, not to hire graduates of non-AACSB schools. Furthermore, many schools advertising for faculty, especially for doctoral and other graduate faculty, already specifically require that the faculty candidates be graduates of AACSB accredited schools of business.

Yet to even consider AACSB certification there are many challenges for a school to overcome before it can seek AACSB accreditation, and with a realistic chance to attain such certification. The qualification of the faculty is a very important area for accreditation purposes; and AACSB is "very stringent" regarding faculty qualifications. One such difficulty for schools, particularly schools that use a great deal of part-time, adjunct professors is the AACSB standard that certain numbers of the faculty, both full- and part-time, must be "academically qualified" $(\mathrm{AQ})$, and others must be "professionally qualified" (PQ). Since many adjunct professors are active practitioners in 
their teaching fields and possess the proper academic degree credentials, the problem for many schools will be the AQ status of the adjuncts (and perhaps some full-time faculty too) since AQ, in essence, means that the faculty must be published in peer-reviewed scholarly journals and present papers at peer-reviewed scholarly conferences. These scholarly activities are typically the work of the full-time faculty and not a school's adjunct faculty. Moreover, if a school uses adjunct professors who teach full-time at other schools, and these professors are AQ, then these faculty members might be regarded as AQ only for their "home" schools; that is, their AQ status will not transfer over to the school retaining them as adjunct professors. While it is beyond the purposes of this article to delve into the exact AQ versus PQ percentages, as well as the number of articles and presentations needed to be AQ, the authors nevertheless want to emphasize that the AQ requirement could emerge as a very difficult issue for some schools. The AQ standards very likely will be much higher for doctoral teaching faculty and also higher for master's teaching faculty than undergraduate teaching faculty.

Another challenging AACSB accreditation issue related to schools using large numbers of adjunct faculty is the status and percentages of the school's faculty regarded as "actively participating." Actually, it is the authors' understanding that AACSB no longer uses the word "adjunct" but rather has a requirement that a certain percentage of the school's faculty, both full- and part-time, be actively participating in the academic life of the school, for example by sitting on faculty meetings and other committees, assisting in program design and revision, helping in the preparation of syllabi and selection of textbooks. Again, it is not the intent of the authors to address specific requirements, especially numerical percentages; yet it must be emphasized that a school may have to make a substantial effort to achieve that actively participating status for many of the part-time faculty as well as to achieve the proper number of actively participating part-time faculty. Plainly, in order to get the part-time faculty to be more active the school may have to pay them more; or the obverse, that is, the school may reduce their numbers by hiring more full-time (and presumably actively participating as well as AQ) faculty members; yet the cost of the latter approach clearly has even greater financial ramifications for a school and its college or university. Another way to meet the AQ and "actively participating" requirements is for a school to create a Master Professor and Professional Specialist or Professional Faculty teaching system, wherein the Master Professor, who would be a full-time, actively participating, and AQ faculty member, be the "professor of record" for a course, whose various sections would be taught by "professionally qualified" but not necessarily AQ and "actively participating" Professional Specialists or Faculty (formerly called "adjuncts"). The Master Professor would supervise the Professional Specialists, produce some core lectures (either in a large lecture hall or online by video), make sure that the course syllabus, learning objectives, and exams are consistent, be available for communication with all the students, for example by chat sessions, and, most importantly, assign the students' grades. The Professional Specialists would teach the sections of the class under the supervision of the Master Professor. For this arrangement to pass AACSB muster, the Master Professor must do more than "merely" supervise, rather, he or she must be actively involved in students' learning and actually assign the learners their grades. However, since the grading is critical here, one of the author's colleagues perceptively discerned that one must be careful, especially if there are several sections to a course and a group exam, that the Master Professor "of record" does not turn into the Master Grader!

Moreover, colleagues warn that there is not a great deal of flexibility with any of these AACSB accrediting standards. Moreover, to truly complicate matters, many of the AACSB standards, in the opinion of some faculty, are a bit vague and not at all precise and exact, and thus subject to interpretation (and perhaps by members of an AACSB accreditation committee who may come from very traditional schools). Nevertheless, all these standards and percentages - AQ, PQ, quality (and especially "quality" as that is a recurring theme of the accrediting standards), actively participating - are applied not "merely" at school of business's main campus site, but rather to all branch campuses, clusters, and academic sites, and to all business programs - ground-based, online, or hybrid delivered at these branch campuses, and sites. Are the concomitant financial ramifications fully thought out? Is a school prepared to drop its doctoral program, or its MBA program, or some of its branch campus sites in order to get the "numbers" right for programmatic accreditation. Is a school prepared to make the financial commitment to hire doctoral faculty who are AQ? Owen (2009) points out that "AACSB's push to accredit more business schools no doubt has had an effect on the number of doctorally qualified faculty that are needed" (p. 6). He also notes that the "...dramatic increase in the number of accredited schools means that there will be more demand for doctorally qualified faculty. Since it is smaller, non-research schools that have been added since the 1992 change in AACSB standards, it also means that many (perhaps most) of these schools need to lower teaching loads, requiring even more faculty than had been necessary prior to thoughts of accreditation. Additionally, the requirement for greater 
numbers of doctorally qualified faculty means that there will be greater demand for faculty who are able to remain academically qualified" (Owen, 2009, p. 6).

The quality of a school of business' programs is a paramount issue for AACSB. Accordingly, it again must be noted that the word "quality" continuously appears throughout the organization's accrediting criteria. This aforementioned quality standard, it has been related to the authors, is much more strictly applied to those schools seeking accreditation with doctoral programs. One former dean related to one of the authors that a business school that has a doctoral program "raises the AACSB bar" for accreditation. As such, the AQ percentages for doctoral faculty will be very high indeed; and the number of peer-reviewed journal articles and presentations will most likely be larger for doctoral faculty. In addition, the "quality" of the scholarship for faculty doctoral faculty will be an issue. How such quality is measured is another perplexing issues, but it should be noted that some schools rank publications as "A, B, or C" journals (There are no "D" journals.); some schools send out articles to faculty at other schools for a quality review, and yet other schools use a "citation index," whereby the direct impact of an "article" can be gauged by the number of scholarly articles that cite it. For doctoral faculty AACSB would expect not only "higher research productivity" but also "higher level journals," and these are "must have" elements of certification.

There may be some "hope" for schools, particularly non-traditional schools, in seeking accreditation. Since most quality control programs tend to be "moving targets" in search of continuous improvement, similarly, AACSB has "evolved," and as a result is no longer a "one size fits all" or a "formula approach" organization, but rather becoming more of a "big tent." As a result, AACSB may now be available for schools that are "not like other schools." This new flexibility has emerged in two key areas: the school's Mission Statement and Assurance of Learning process. An artfully crafted as well as accurate Mission Statement can provide some help to schools seeking accreditation, as a focal point of AACSB's examination of a school will be its mission statement. So, for example, take a school that is primarily a teaching school, and perhaps also not a traditional one, but rather an innovative one that uses online and hybrid formats, weekend and night programs, and branch campuses and sites in order to reach students not usually served by more traditional schools. The mission statement could also emphasize the practical and applied elements to the student's education, and thus the worth of practitioners as teachers and researchers might be more readily recognized. The mission statement of such a school should naturally emphasize these elements, and though the mission statement will not totally obviate AACSB standards, it should afford a school some latitude, as well as effect to the school's benefit a more liberal interpretation of AQ and research quality criteria. A mission-driven AACSB strategy, therefore, is an essential element to a school's accreditation effort.

Assurance of Learning emerges as a major component of accreditation, as well as one that might afford a school a bit of flexibility in seeking or maintaining accreditation. Though it is not the purpose of the authors to deal with the very important and complex topic of learning outcomes and Assurance of Learning, nonetheless some basic points must be made. First, in essence, this Assurance of Learning process is based on creating testing items, and then assessing what the students are learning, or perhaps not learning, by pre- and post-testing. Note that this assessment should occur not merely at the course level but also at the degree and program level. Though such assessment will involve a considerable amount of work for a school, it is naturally important to assure the school's own stakeholders as well as accrediting bodies that the students are actually learning what they are supposed to learn. One important aspect of this outcomes examination will be to ascertain if the students are learning the objectives of the courses and the program. To illustrate one way for schools to use this Assurance of Learning process to help with its accreditation efforts, consider, for example, a school with no GMAT or GRE requirements, or a school with lower GMAT or GRE scores, or a school with lower GPA standards than other accredited schools. If it can be shown that the students admitted with lower scores and averages nevertheless are shown to be demonstrably learning and, even better, ultimately successful in business or the professions, then such a school could well argue that its lack of a GMAT or GRE and/or lower "numbers" should not be an impediment to accreditation. Yet, when it comes to accreditation, a school better be able to show the accrediting body its assessment and outcomes data. Merely "saying you did it" will be insufficient; rather, a school must prove its effectiveness by means of its data and continuous improvement so as to "close the loop."

There are also risks associated with some programmatic accreditation elements if it is going to force an institution to assimilate and become more traditional. So, a major risk to accreditation is that it might "homogenize" a school of business, and thus make it bland, and eventually non-competitive. If a school has been very successful 
by being innovative and entrepreneurial, and is so regarded in the business and academic communities, it must be careful not to lose these important values in an effort to secure accreditation. The objective very well might be to achieve the AACSB imprimatur, yet not at the cost of a school losing its vibrancy or the values of innovation, creativity, and entrepreneurship. Otherwise, "winning" the accreditation "battle" might be only a "Pyrrhic victory."

Another serious risk is that some of the faculty might view seeking AACSB accreditation as a threat as opposed to an opportunity. Faculty, as human beings, likely will have a certain "comfort level" with the status quo. This status quo may include a very loose or lax or non-existent scholarship policy. Change, therefore, particularly such an accreditation effort, may engender fear, worry, dismay, or even anger. This fear and disquietude must be addressed by the school administration and the faculty as a whole. The "opportunity" element must be emphasized, and accordingly it must be stated plainly that everyone can make a contribution, everyone has a role to play, and everyone therefore will be proud when accreditation is attained. As emphasized, faculty support is critical for accreditation success. Actually, the ideal situation would be for the impetus for accreditation to have come "up" from the faculty, and not "down" from the school's administration. In addition to impeding a school's "culture" for entrepreneurship and innovation, a school must also be very careful that an accreditation effort not disturb, hinder, or destroy a culture of collegiality among the faculty members. Accreditation, therefore, must be faculty "driven" and the faculty thus must be included in any initial accreditation feasibility studies. Everyone must be "on board" with the mission of the school and university.

Another risk of AACSB accreditation is that it may hinder innovation and entrepreneurship in the area of joint programs, for example, with a school's medical, nursing, science, and engineering schools. Combining the aforementioned fields with business in a joint degree program could be a "win-win" scenario for the students, the schools, the university, and the community. However, one must be cognizant of AACSB requirements that these joint programs, in order to be called "business" programs, must have certain percentages of business school faculty teaching the courses and these faculty must meet AACSB's AQ and "actively participating" requirements.

In looking at the number and names of schools of business accredited by the AACSB, one can see in addition to the large, established state schools and other well-recognized private schools, possessing excellent reputations, many other schools, not as well known, established, or prestigious, which nonetheless have achieved the very prestigious AACSB label. Such a fact militates against a charge that the accrediting body is "elitist"; yet it should be pointed out, as the discerning reader has already perceived, that it will be much easier for a smaller school, primarily undergraduate, with not many academic campuses or sites from the main campus, to attain AACSB status since the "correct" numbers of actively participating, AQ faculty will be easier to obtain. The bigger and more farflung a school is, and the more graduate programs it has, and especially if it has a doctoral program, the greater the hurdles will emerge that will have to be overcome in order for a school to "win the race" for AACSB certification. The AACSB might be less stringent in applying its standards to a school with an undergraduate program only, or perhaps a small master's one, rather than schools with large graduate programs, particularly doctoral programs. There also may be an inherent conflict between a school's desire to have a more practitioner-oriented faculty and AACSB faculty standards. So, Maidment, Coleman, and Bazan (2009) in their study of Executive MBA programs (EMBA) note that since "...EMBA programs tend to be pragmatic and applied in nature, it would be interesting to see if more practitioners could be deployed to the EMBA classroom. Doing so might provide an even more applied focus in certain courses and might help conserve the load credit of full-time faculty for other activities" (p. 7). Nonetheless, they warn that "if this alternative is considered, the standards for professional qualifications of the AACSB would have to be fully considered" (Maid, Colemand, and Bazan, 2009, p. 7).

There are, therefore, many challenging questions that will arise in a school's quest for AACSB status. Consequently, difficult decisions will have to be made by the school and university as to whether AACSB accreditation, or any alternative accreditation, makes sense for the school of business and the university. The authors, as emphasized, are not AACSB experts by any means; but they certainly would advise that before a school considers such an accreditation that the faculty and school administration, the college or university administration, as well as other school "stakeholders," are completely aware of the work involved and the financial implications of seeking accreditation for the school and college or university, and that all the school's "stakeholders" are fully committed to the process. The costs have to be counted; and sacrifices may have to be made. AACSB accreditation is an "end" but it is also a "means" to an end, and thus must be an integral part of a school and university's strategic 
plan. It should be noted that seeking AACSB accreditation could involve a "tremendous cost" in resources, and might even "destroy" a school's successful business model. Consequently, the authors would strongly advise that before a school and university even entertain the prospect of the business school seeking AACSB status, the school hire an AACSB consultant or an advisory board to advise them, and then later on, if the process is initiated, an AACSB "mentor" to further counsel the school. Yet no consultant or mentor can advise as to AACAB accreditation unless the school and university ascertain what the financial "hit" will be. What is the old military saying, still very true in this academic "battle": "What general goes to war without counting the cost"?

\section{FACULTY RESEARCH AND SCHOLARSHIP}

Faculty research and scholarship are naturally very important activities at a school of business, and, as noted, they emerge as essential activities for a school seeking programmatic accreditation (such as IACBE or AACSB). Scholarship is so important since everything in business, in essence, is transitional, so the faculty must stay current. For example, as well as known to the readers of this article, a textbook, due to the lengthy process of publication, is really "old" when published. Scholarship supplies intellectual stimulation, thereby forcing faculty to keep thinking and to keep asking questions - questions that will be asked to the students. Scholarship is important not merely in and of itself in producing knowledge, but also in making one a better teacher. Scholarship, therefore, is a critical part of good teaching, especially in today's world of fast-moving and rapid changes.

Yet what is the proper degree of research and writing? The answer depends on the nature of the business school. There is clearly a difference between a primary research type business school, where scholarship is extremely important, and a middle-ground or mid-tier school, where there is a balance between teaching and research, and a primarily teaching type of business school. In even the latter type of teaching school, the authors nevertheless strongly believe that some research and scholarship by the faculty is important, and thus necessary in order to keep the faculty current and to enhance the quality of their teaching. At the undergraduate and master's levels, scholarship can be more of the "applied" type of research and writing, particularly with a company or industry focus; whereas at the doctoral level the focus of the scholarship should be on validating and creating new knowledge. The authors believe that some academic scholarship, though valuable in the "halls of academe," may be a bit too "pure," that is, arcane and abstruse, for practical business use, and consequently such research does not have a direct positive impact on society. Certain business school professors, it seems, know more about academic publishing than they do about the real-world problems in the workplace. The goal, the authors believe, is to produce scholarship that is regarded as an intellectual contribution, but also contains an "applications" component so that the scholarship is regarded as direct and measurably valuable and value-producing by the marketplace. Showing managers and teaching students how to manage, that is, how actually to accomplish objectives with and through employees and other people, should be a duly recognized part of academic scholarship as well as teaching. Such "real-life" research keeps a faculty member "engaged," and as a result makes him or her better in the class as well was more valuable to the business and management community. Consulting by faculty members certainly should be permitted if it is valuable to the client and produces value to the marketplace. The authors firmly believe that business school faculty should always have a connection to the business community; such a nexus will make the faculty member's research as well as teaching more relevant and valuable. However, regarding consulting, one principal goal of consulting would be to convert the consulting endeavor, which could be writing an economic impact statement or working with a start-up on an IPO, into a peer-reviewed journal article or case study. A faculty member, therefore, could develop a portfolio of intellectual contributions that combine peer-reviewed journal articles, presentations at conferences (which ideally should be peer-reviewed and then published in full or at the least abstract form in the proceedings of the conference), books, book chapters, and book reviews, and case studies (preferably peer-reviewed, of course). Yet research and writing, as with all activities in a school of business, must be in alignment with the mission, vision, and principles of the school as well as the school's accreditation requirements, and they must conform to a mission-driven definition of "quality." A key question to answer, related to the school's mission, is what "market" the faculty member is writing to. Is the research highly theoretical that is valued by "pure" academics, or is it practical and applied, relevant to business, and thus of value to a corporation and the industry? Moreover, as a very practical matter, it must be pointed out that a school of business may not have the resources necessary to support a faculty member who wishes to publish theoretical type of research in a "top" journal. As emphasized, a school must be very clear and certain as to its mission, the viability of its mission in the marketplace, and the school and university resources necessary to fulfill that mission. 
Any scholarship is, of course, related to the teaching course "load" of the faculty. Generally speaking, it seems that the standard norm is three courses for nine credits for each of the two traditional semesters for a total of 18 credits a year (with opportunities for additional summer teaching perhaps). However, that typical teaching responsibility could (and should in the authors' opinion) be further reduced for faculty teaching at the master's and especially the doctoral level, where the scholarship requirements in both quantity and quality will be more demanding. Course reductions for scholarship could always be considered on an individual basis, though granting such teaching releases may be constrained by economic considerations. Moreover, at some schools, support for scholarship is very tangible; as such, there are cash incentives, for example, point systems are used to compensate a faculty member who produces a certain amount of scholarship; and when a certain number of points are achieved the faculty member is given a course release or a monetary payment equivalent to teaching one "overload" course. Other schools simply make payments, $\$ 1500$ was one amount related to one of the authors by a former dean, for peer-reviewed journal articles deemed to be "valuable." Nevertheless, it also must be pointed out that AACSB officials tend to "frown" upon a doctoral faculty member teaching a faculty "load" which is in most schools the usual undergraduate teaching "load." There thus should be a relationship between teaching "load" and research productivity, and particularly for a faculty member designated as "research faculty."

The authors have always felt that faculty should be encouraged to be active researchers and motivated to publish by support and positive reinforcements, such as reduced teaching "loads," training, especially as to research methods and statistics, mentoring, collaboration, support for attending conferences, research and editing support, and further support to convert paper presentations at conferences into peer-reviewed journal articles. One way to produce scholarship is to engage a faculty member in an area of real interest to the faculty member; that is, find out what the faculty member cares about and what he or she has a passion for; next, match the faculty member to this business area or entity; and then encourage the faculty member to do some research; and finally help the faculty member publish the results of this research as an article or case study. Collaborative efforts naturally should be encouraged in this endeavor. The "carrot," therefore, the authors firmly believe, is better than the "stick"; yet the authors are cognizant of the fact that some schools may utilize the "stick," in the form of denial of promotions or summer teaching work, in order to "encourage" research and writing. It may be necessary to produce scholarship, especially as part of an accreditation effort to "ruffle some feathers" with the faculty. At the very least, if any "ruffling" is to be done, or any "stick" is to be used, it is imperative that the school administration proactively inform the faculty of the policy, explain it, and state the rationales behind the policy, and not merely imperially announce it to the faculty.

\section{STUDENT RECRUITMENT, RETENTION, AND DIVERSITY}

Finding, recruiting, and retaining students, while maintaining quality, are not easy tasks. Owen (2009) states that the assumption that student enrollments at schools of business will continue to rise, as they did in the late 1990's, may be erroneous. The reason Owen gives is simple and straightforward - the deteriorating economy. Employability is the key factor, and the recent unemployment and continuing layoffs consequently will reduce business student enrollments, especially of finance majors and MBA students. Owen reports "declining" MBA applications, and he predicts "dramatically fewer finance majors in the future" $(2009, \mathrm{p}$. 7). One solution to this decreasing student enrollment is to create and offer differentiated and specialized programs that are exciting and innovative, and that allow the students to grow and develop. Making the educational opportunities available to the students at convenient times and places, either by ground sites (whether branch campuses, academic centers, cluster sites, or corporate sites) or in an online format, is an important ingredient to recruitment and retention. The flexibility of a school's programs is an important "selling" point, especially for working adults, and particularly for MBA programs, which could be one year full-time or two years in an evening, weekend, or online format, or in a hybrid ground and online format. Another key factor will be to demonstrate to potential students (and also the companies that furnish their tuition) that their education will provide direct, immediate, and measurable value to themselves and their companies; and that they will receive an immediate tangible return for their tuition dollars. Companies must be shown that by funding students they will receive a more educated, knowledgeable, and skillful workforce, and thus receive a return on their educational investment in their employees. Offering specialized certificate type programs that target industries where education is in high demand, such as health care, emerges as a good tactic, not only to attract executive education type students, but also to convert some of them to traditional students as well as to establish corporate "cluster sites" at their companies. International recruiting should of course 
be considered, and joint programs with foreign schools may be a way to bring more students to one's school. Yet, as noted, a school must be sure that the standards for admission and graduation for foreign students must be the same as the school's "regular" students; otherwise, accreditation problems could ensue. Many schools establish relationships and alliances with community colleges whose students can transfer over to a school in their junior year. Deans and associate deans should visit community colleges on a regular basis to "show the flag." Programs also could be established as "cohort" programs where the students, particularly graduate students would take all of the same courses on the same sequence, thereby creating a common personal, academic, professional, and networking bond. Schools should "spotlight" who can reach out to the community, and thus schools should produce community events that highlight students, especially minority students. The media, especially the very cost effective community radio networks should be used to advertise the school and its programs. Such advertising, however, should "stay on point," and thus emphasize programs where the school has a clear, differentiated, competitive advantage. Yet, at a more basic level, schools should use students to bring in their friends as potential students for the school. A school web page could be created with vignettes by students. Schools could also attract students, as well as burnish their reputation in the community, by using speakers, on ground but also on the radio, where a business show could be created, with certain (and compensated) faculty speaking on a current topic and answering questions, or with business entrepreneurs being identified and interviewed. The goals, of course, are to enhance the school's reputation, obtain good students (and then to keep them), as well as to do some "friend-raising" which hopefully will lead to some fund-raising.

The authors cannot sufficiently emphasize how important "customer service," advising and counseling, and mentoring are when it comes to the students staying in school and having a good and productive educational experience. It is imperative that students can talk to a real person, whether a faculty member, advisor, or the dean him or herself. The "human element" is critical. Prospective students could be briefly introduced to faculty members, and perhaps a faculty member or even the dean himself or herself could conduct the tour of the business school. Providing academic assistance to the students, for example, in the form of tutorials, writing and language labs, and technology workshops, is also very important. Outreach to the community is essential, particularly for attracting minority, women, and other under-represented students. Achieving a diverse student body may be difficult for some schools, perhaps just due to geography; but such a goal is a very laudable one for the school and a very beneficial result for all the students. Perhaps a rural or suburban school could do some recruiting in the central cities in order to seek out under-represented students. Diversity should be part of the normal academic process for a school and university. The idea is to create a true learning global community that is diverse, multi-national, multicultural, and multi-lingual; and thus a community that reflects the "real world" the students will live and do business in. There even could be a business college dorm with a diverse business major student body. The fact that the students have similar interests would be most helpful in acclimating the students, especially the international students, to campus life, and would provide a support and networking system. The benefits of having a diverse student body for all the students are well known. Yet one problem for schools that have been successful in attracting minority students is that in these difficult economic times some of these students may not have the financial ability to commence, and then continue with, their studies. One solution is the use of scholarships and grants, of course; and a solution for those that have dropped out is for schools to create "reclamation" programs with reduced tuition and substitute courses.

Advising and counseling students are critical activities for a school, obviously, and all faculty members must take part in such efforts. Small classes are of course desirable, but such small size can be problematic in difficult economic times. Yet even if undergraduate classes are very large, nonetheless there can be supplemental lectures online as well as "breakout" sessions with professional specialists and business leaders so as to combine theory and practice. Overall, faculty members, staff and administrators must work together to create an ethical institution (Mujtaba and Cavico, 2009) and a joyful learning environment for each and every one of their students. As stated by the authors in a previous publication:

Faculty and staff who trust their dean, and who are guided and governed by rightful purposes and principles, will feel authorized to achieve worthwhile objectives. Such people will possess a sense of stewardship; that is, they will act effectively to accomplish communal goals, govern themselves and others accordingly, and convince others to lead and make a contribution. A successful dean is committed to this principle of opportunity and shared leadership; and he or she will empower, encourage, and educate followers and employees to act, to lead, to bring out the best in 
themselves and others, and to achieve personal and organizational success. Such a discerning, encompassing, and enabling conception of leadership is also a most efficacious one...The challenge for a leader is to align his or her personal goals with the goals of the school, university, or organization, and also with the needs and aspirations of the leader's followers and employees, and to ensure that this alignment is centered on a crux of morality and legitimacy. Only then can a leader - academic dean or otherwise - truly lead and thereby achieve permanent positive transformation (Cavico and Mujtaba, 2009, pp. 8-9).

\section{SUMMARY}

The economic recession of the last few years did have one "good" effect; that is, it made the world more global, made it more global in a very short and compressed time period, and made that global context very "loud and clear." Accordingly, it should be clearly aware to all, that in this "new economy," in the words of the old poem, that "no one is an island." The world economy, as was convincing and depressingly indicated, is just too interconnected for any nation to live as an island. Business schools must of course be aware of this "new reality"; and they may have to change their business models to reflect the shifting nature of markets and the economy to a global context. Accordingly, business schools now must be innovative and entrepreneurial, and be willing to take some risks, in order to take the lead to build global coalitions to produce students who will be global leaders. The goal, therefore, is for business schools to meet the demands of their students and to make a positive contribution to their communities, society, and the world. Business and management should be perceived like law and medicine as a "noble profession" - one that creates wealth but also brings economic vitality to their communities and society, and ultimately to transform people's lives.

Business schools and ultimately business students naturally will make business decisions, yet such decisions must be balanced by the needs of the school's and society's stakeholder groups. The administration, faculty, and students must "buy into" the school's mission, vision, and core values and principles; and then they all will want to make their "mark," a positive mark, in higher education and society, and grow and prosper with their schools, communities, society, and the world. Business schools should be leaders in bringing forth not "merely" economic growth and vitality but also morally and socially responsible behavior; and thus business schools should, and must, produce business leaders who can effectuate positive, value-maximizing change on a global and sustainable basis.

\section{AUTHOR INFORMATION}

Frank J. Cavico is a professor of Business Law and Ethics at the H. Wayne Huizenga School of Business and Entrepreneurship of Nova Southeastern University. In 2000, he was awarded the Excellence in Teaching Award by the Huizenga School. In 2006, he was honored as Professor of the Year by the Huizenga School. Professor Cavico holds a J.D. degree from St. Mary's University School of Law and a B.A. from Gettysburg College. He also possesses a Master of Laws degree from the University of San Diego School of Law and a Master's degree in Political Science from Drew University. Professor Cavico is licensed to practice law in the states of Florida and Texas. He has worked as a federal government regulatory attorney and as counsel for a labor union; and has practiced general civil law and immigration law in South Florida.

Bahaudin G. Mujtaba, D.B.A., has served as Department Chair, Director of Accreditation and Outcomes Assessment, Director of Undergraduate Business Programs, and an Associate Professor of Management and Human Resources at Nova Southeastern University's H. Wayne Huizenga School of Business and Entrepreneurship. Bahaudin has served as manager, trainer, and management development specialist in the corporate arena as well as a director, department chair and faculty member in academia. His areas of research are ethics, outcomes assessment, management, and diversity management. 


\section{BIBLIOGRAPHY}

1. AACSB 2009 Accreditation standards changes and updates. The Association to Advance Collegiate Schools of Business. http://www.aacsb.edu/accreditation/standardsreport-revised23Jan09, retrieved June 28, 2009.

2. Alsop, Ron (September 18, 2007). Hass Takes New Tack on Investing: M.B.A. Students to Run Fund Focusing on Socially Responsible Firms. The Wall Street Journal, p. B8.

3. Alsop, Ron (June 19, 2007). Why Teaching of Ethics Continues to Be Lacking. The Wall Street Journal, $p$. B7.

4. Anders, George (September 26, 2007). Business Schools Forgetting Missions? The Wall Street Journal, $p$. A2.

5. Bedeian, Arthur G. (2002). The Dean's Disease: How the Darker Side of Power Manifests Itself in the Office of the Dean. Academy of Management Learning and Education, Vol. 1, No. 2, pp. 164-73.

6. Bennis, W. G. and O'Toole, J. (2005). How business schools lost their way. Harvard Business Review, 83(5), pp. 96-105.

7. Brant, Martha and Ohtake, Miyoko (April 14, 2008). A Growth Industry: Business schools are teaching entrepreneurs how to get rich helping to save the environment. Newsweek, p. 64.

8. Cavico, F. J. and Mujtaba, B. G. (2009). The State of Business Schools, Business Education, and Business Ethics. Journal of Academic and Business Ethics, 2, 1-18.

9. Derrick, M. Gail and Carr, Paul B. (December 2008). Global Learning and Education for the $21^{\text {st }}$ Century. HRM Review, pp.16-19.

10. Dizik, Alina (April 15, 2009). A Business School Learns to Specialize. The Wall Street Journal, p. D4.

11. Dvorak, Phred (February 12, 2007). M.B.A. Programs Hone "Soft Skills." The Wall Street Journal, p. B3.

12. Ghoshal, S. (2005). Bad management theories are destroying good management practices. Academy of Management Learning and Education, (4(1), pp. 75-91.

13. Glader, Paul (June 22, 2009). The Jack Welch MBA Coming to Web. The Wall Street Journal, B1, B2.

14. Green, Hardy (November 5, 2007). Are B-Schools a Blight on the Land? Business Week, p. 90.

15. Jacobs, M. (2009). How business schools have failed business. The Wall Street Journal, A13; Friday, April 24, 2009.

16. Locke, Michelle (September 25, 2007). Balancing profit, planet. The Miami Herald, p. 4C.

17. Maidment, Fred, Coleman, John, and Barzan, Stan (2009). Characteristics of Executive MBA Programs at Public Colleges in the United States. Research in Higher Education Journal, Volume 4, pp. 1-9.

18. Merritt, Jennifer (October 18, 2004). Welcome to Ethics 101: B-schools are trying a host of new methods to teach MBAs lasting lessons in leadership principles. Business Week, p.90.

19. Mitroff, I. I. (2004). An open letter to the deans and faculties of American business schools. Journal of Business Ethics, 54, pp. 185-189.

20. Mujtaba, B. G. and Cavico, F. J. (2009). Making the case for the creation of an academic honesty and integrity culture in higher education: reflections and suggestions for reducing the rise in student cheating. American Journal of Business Education, 2(5), 75-88.

21. Neubaum, D. O., Pagell, M., Drexler Jr., J. A., McKee-Ryan, F. M., and Larson, E. (2009). Business Education and Its Relationship to Student Personal Moral Philosophies and Attitudes Toward Profits: An Empirical Response to Critics. Academy of Management Learning and Education, 8(1), pp. 9-24.

22. Nonis, S. and Swift, C.O. (2001). An Examination of the Relationship between Academic Dishonesty and Workplace Dishonesty: A Multicampus Investigation. Journal of Business Ethics, 77(2), pp. 69-76.

23. Owen, Robert S. (February 2009). Managing a U.S. Business School Professor Shortage. Research in Higher Education Journal, Volume 2, pp. 1-10.

24. Schmalensee, Richard (November 27, 2006). Where's the 'B' in B-Schools? Business Week, p. 118. 